\title{
The Capital Account and Pakistani Rupee Convertibility: Macroeconomic Policy Challenges
}

\section{Irfan ul Haque*}

\begin{abstract}
Pakistan embarked on the liberalization of its capital account more than two decades ago. Today, it is an economy with a capital account that is, by and large, free of restrictions, and a convertible currency. However, its actual integration into the global economy in comparison to other emerging market economies has remained rather limited. The opening of a capital account appeared to have improved the country's access to private foreign capital, but because of domestic security and economic and political concerns, the inflow of private capital has fallen in recent years. Although capital outflows were not a major cause for the decline in foreign exchange reserves during Pakistan's economic crisis of 2008, the open capital account and rupee convertibility have made it more vulnerable to outside shocks. This article identifies three areas where policymakers in Pakistan face serious challenges, i.e., macroeconomic management; controlling tax evasion, which the Pakistani rupee's convertibility has made easier; and minimizing the real cost of portfolio investment to the country. The article offers ideas on how these challenges could be met.
\end{abstract}

Keywords: Capital Account, Covertibilty, Pakistan.

JEL Classification: E22, G11, H26, O16.

\section{Introduction}

Capital account liberalization is a keenly debated issue. On one side, with the support of mainstream economic theory, free capital flows are held to promote efficient allocation of investable resources because investment can move from less profitable (implying less efficient) to more profitable locations. When accompanied by trade liberalization, open capital markets and flexible exchange rates reinforce and facilitate international specialization in trade on the basis of comparative advantage.

\footnotetext{
* Special Advisor Financing for Development, South Centre, Geneva. The usual disclaimers apply.
} 
However, capital account liberalization ${ }^{1}$ has also been seen to make economies more vulnerable to international financial crises, especially in the developing world. Reckless commercial bank lending led to the Latin American debt crisis of the 1980s, costing the entire region a whole decade of economic growth. Aggressive trade liberalization and an open capital account brought Mexico to its knees in 1994, when it was made to pay for its over-exposure to short-term capital. Three years later, there was the wrenching East Asian currency and financial crisis, which caused massive economic and financial disruption and thwarted economic growth in Thailand, Indonesia, and Korea, while touching many other countries in the region.

In recent years, emerging market economies have experienced a rather different problem, although still caused by hot money flows. With interest rates falling to near-zero levels thanks to monetary easing in the leading industrial countries, investors have sought opportunities in some of the emerging market economies, where interest rates-because of domestic macroeconomic imperatives—have been significantly higher. Among others, Brazil, South Africa, India, and Singapore have experienced large capital inflows that have put pressure on their currencies to appreciate. The affected countries have tried to stem this inflow through various measures (notably, taxing short-term inflows) but with limited success. This problem has led the International Monetary Fund (IMF) to recognize that capital controls may be justified in certain conditions.

Pakistan started on the course of capital account liberalization and exchange convertibility in the mid-1980s, quite early compared to other developing countries. Indeed, this process started even before Pakistan took steps to bring down tariff barriers and liberalize its trade regime. The rupee has now been more or less freely convertible since the early 1990s and capital movements face few hurdles. Has this helped or hindered Pakistan's economic progress? To what extent have these measures facilitated or constrained the design and implementation of macroeconomic policy in Pakistan? This article attempts to address these questions.

The following section explores how open the Pakistan economy really is, since clarity on this question is essential to a discussion of macroeconomic policy. This is followed, in the third section, by an exploration of the impact of capital account liberalization on Pakistan's

1 “Capital account liberalization," “open capital account,” and “financial globalization” refer essentially to the same phenomenon, although they have subtle contextual nuances. In this article, they are used interchangeably. 
economy. This lays the foundation for a discussion, in Section 4, of the macroeconomic policy challenges that an open capital account and rupee convertibility pose for Pakistan's policymakers. The final section offers a few concluding observations.

\section{How Open is the Pakistan Economy?}

The openness of an economy can be looked at in two ways: (i) by tracing the actual measures a country has taken to liberalize and open up its capital account and foreign exchange regime (de jure indicators), and (ii) by examining the economy's actual integration into the global economy in terms of trade and financial flows (de facto indicators). ${ }^{2}$ How Pakistan measures up to these indicators is discussed in this section.

\section{De Jure Indicators}

Foreign currency accounts (FCAs) were introduced in Pakistan as early as 1973. The intention here was to attract foreign earnings of an increasing number of Pakistanis working overseas by making available to them a reliable, attractive, and safe savings instrument at home. The real motivation behind this step was the government's pressing need to finance fiscal deficits while gaining access to foreign exchange that was, as always, in short supply (see Mirakhor \& Zaidi, 2004).

However, the first major step to liberalize the capital account and exchange rate regime was taken with the introduction of foreign exchange bearer certificates in 1985, which foreigners or Pakistanis could purchase with foreign exchange. ${ }^{3}$ Six years later, in 1991, all foreign exchange controls were removed and the Pakistani rupee became more or less fully convertible. Within a few months, dollar bearer certificates (DBCs) were introduced, which was a significant development for a variety of reasons. These certificates, which carried a maturity period of one year, were denominated in US dollars and carried an interest rate linked to the London Interbank Offered Rate (LIBOR), not to domestic money market rates. The certificates could be cashed in Pakistani rupees, US dollars, or any other foreign currency at the prevailing exchange rate. However, more consequential was the government's foreswearing to ask questions

\footnotetext{
2 This is a common approach to measuring global integration in trade (see, for example, Dollar \& Kraay, 2001). In the context of capital account openness, Prasad (2009) adopts a similar approach.

3 Much of the factual information in this and the next few paragraphs is taken from Historical exchange rate regime of Asian countries, University of Hong Kong, retrieve from http://intl.econ.cuhk.edu.hk/exchange_rate_regime/index.php?cid=22
} 
concerning the sources of funds used to purchase DBCs or to open FCAs. This was, in essence, an open invitation to Pakistani residents to evade tax payment and launder money.

Further refinements to the capital account and foreign exchange regime continued in the succeeding years, culminating in early 1998, when banks were allowed to quote their own currency conversion rates within the buying and selling bands fixed by the State Bank of Pakistan (SBP). However, the process came to a sudden halt just a few months later. FCAs-which were freely allowed and had become popular with both resident and nonresident Pakistanis-were frozen literally overnight. This was a clumsy and poorly managed response to the imposition of severe economic and financial sanctions on the part of the US, Japan, and European countries, as punishment for the May nuclear tests.

The FCA freeze was accompanied by the introduction of a multiple exchange rate system comprising an official rate, an interbank rate, and a composite rate, although banks could still quote their own currency conversion rates. However, since the IMF generally regards multiple exchange rate regimes with disfavor, the issue became an irritant during negotiations for a standby agreement that Pakistan desperately needed to cope with the financial stringency resulting from the sanctions. In mid-1999, the system of multiple exchange rates was, however, abandoned, and a unified exchange rate was reintroduced. The rupee was once again declared free to float, but was effectively pegged to the US dollar within a specified narrow range.

The liberalization process continued during the Musharraf era but the focus shifted to making the foreign exchange regime more transparent and efficient, and improving supervision of the institutions involved. The formation of exchange companies was seen as an important step in curbing-and eliminating-unauthorized moneychangers, who had become important players in the liberalized environment. A major goal was to narrow the differential between the open, kerbside rate and the interbank exchange rate and have home remittances channeled through the banking system rather than through the informal system of hundi and hawala. Around the same time, a swap desk was set up at the SBP to ensure liquidity in the foreign exchange forward market, and to rationalize forward premiums, a step seen to help both foreign exchange traders and the interbank market (SBP, 2003). 
By 2008 , the liberalization process was virtually complete and the IMF (2008) could conclude:

All current international transactions are conducted in the interbank foreign exchange market. Importers, exporters, and businesses are free to shop around for the best possible rates in the interbank market for all exchange transactions without recourse to the central bank. Banks may purchase foreign exchange from exchange companies (ECs) at freely negotiated rates. Individuals may purchase foreign exchange through the interbank or EC foreign exchange market in accordance with regulatory provisions. Some government foreign exchange transactions (e.g., debt service payments, conversion of privatization proceeds) are conducted directly by the State Bank of Pakistan, at the rates determined in the interbank market (p. 1061).

In brief, the current situation is:

- Residents or nonresidents can open FCAs at commercial banks with remittances from abroad, foreign travelers' cheques, or foreign currency in cash, but not with income from export or similar activities.

- Nonresidents or foreign firms may open domestic currency accounts that are fully convertible into foreign currency, so long as foreign funds are channeled through the banking system.

- Nonresidents may acquire listed securities with remittances from abroad with no restrictions on the repatriation of capital gains, dividends, or receipts from the disposal of such securities.

- Nonresidents are free to trade in registered corporate debt instruments and bonds listed on the stock exchange, federal investment bonds, or Pakistani investment bonds as well as market treasury bills. Branches of foreign banks and foreign-controlled investment banks may also engage in these activities.

Today, the only salient restrictions on the capital account relate to the limits on the amount of domestic currency that a traveler may physically carry overseas (PKR500 to India and PKR3,000 to other countries) and on the amount Pakistani residents may hold in overseas bank accounts (a maximum of USD1,000 in all countries other than India, Bangladesh, Afghanistan, and Israel, where Pakistani residents may not own any bank accounts.) 
The reform of the domestic financial sector was an essential accompaniment to the opening up of the capital account. ${ }^{4}$ This process stretched over more than a decade and consisted of granting the SBP autonomy, improving the regulatory and supervision system, privatizing nationalized banks, liberalizing foreign bank entry and operations, moving toward "market-determined" interest rates, and eliminating financial repression (Haque, 2010). The results of these reforms were impressive not only in terms of the growth of bank deposits and advances-which reached 40 and 30 percent of gross domestic product (GDP), respectively, in 2007-but in the rapid growth of the financial sector as a whole, reaching an annual rate of 17 percent between 2003 and 2007. The sector also attracted some USD4 billion in foreign investment.

\section{De Facto Indictors}

Global integration takes place through international trade and the movement of capital across countries. Thus, the magnitudes of international trade and international capital flows relative to a country's GDP provide a fair indication of its integration into the global economy. Since capital movements across countries are meant to narrow differences in investment returns (allowing for country and exchange rate risk), the behavior of a country's stock market relative to other leading markets could also provide an idea of its global financial integration.

Table 1 provides the salient indicators of openness during 2004-09 for Pakistan, while Table 2 gives similar indicators for India and a few other Asian economies for 2004-08.5 The ratio of foreign trade (i.e., exports plus imports) to GDP for Pakistan fluctuated between 40 and 45 percent during 2004-08, but fell sharply to 35 percent in 2009 because of the economic crisis. The same ratio for Sri Lanka or Indonesia was considerably higher, close to or exceeding 60 percent (Table 2). However, India's position was rather different: the trade ratio was initially of the same order of magnitude as Pakistan's, but it gradually rose to about 50 percent of GDP. In other words, the two countries were more or less similarly placed with respect to openness to foreign trade just a few years ago, but India became considerably more globalized over time.

\footnotetext{
${ }^{4}$ The significance of the financial sector reforms is that they are regarded as "threshold conditions" for integration into the global economy (Prasad, 2009). Eichengreen, Gullapalli, and Panizza (2009) maintain that capital account liberalization benefits countries with "relatively well-advanced financial systems" along with sound accounting standards and creditor rights, etc.

5 The World Bank's World Economic Indicators 2010 (the source of Table 2) does not contain the data for 2009.
} 
Table 1: Indicators of Openness-Pakistan

\begin{tabular}{lrrrrrr}
\hline Indicators & $\mathbf{2 0 0 4}$ & $\mathbf{2 0 0 5}$ & $\mathbf{2 0 0 6}$ & $\mathbf{2 0 0 7}$ & $\mathbf{2 0 0 8}$ & $\mathbf{2 0 0 9}$ \\
\hline In USD million & & & & & & \\
Total trade (goods and services) & 38,072 & 48,392 & 55,668 & 59,550 & 73,410 & 57,498 \\
Current transfers & 7,666 & 9,169 & 11,030 & 11,215 & 11,252 & 12,552 \\
Of which: & & & & & & \\
Workers' remittances & 3,943 & 4,277 & 5,113 & 5,992 & 7,025 & 8,701 \\
Residents' FCAs & 576 & 330 & 117 & 455 & -51 & 317 \\
Unspecified transfers (residual) & 3,120 & 4,562 & 5,800 & 4,768 & 4,278 & 3,534 \\
Private investment inflows & 1,510 & 3,107 & 6,246 & 7,671 & 5,195 & 1,756 \\
Of which: & & & & & & \\
FDI & 1,118 & 2,201 & 4,273 & 5,590 & 5,438 & 2,338 \\
Portfolio investment & 392 & 906 & 1,973 & 2,081 & -243 & -582 \\
As a percentage of GDP & & & & & & \\
Total trade (goods and services) & 38.9 & 44.2 & 43.7 & 41.6 & 44.8 & 35.5 \\
Current transfers & 7.8 & 8.4 & 8.7 & 7.8 & 6.9 & 7.7 \\
Of which: & & & & & & \\
Workers' remittances & 4.0 & 3.9 & 4.0 & 4.2 & 4.3 & 5.4 \\
Residents' FCAs & 0.6 & 0.3 & 0.1 & 0.3 & 0.0 & 0.2 \\
Unspecified transfers (residual) & 3.2 & 4.2 & 4.5 & 3.3 & 2.6 & 2.2 \\
Private investment inflows & 1.5 & 2.8 & 4.9 & 5.4 & 3.2 & 1.1 \\
Of which: & & & & & & \\
FDI & 1.1 & 2.0 & 3.4 & 3.9 & 3.3 & 1.4 \\
Portfolio investment & 0.4 & 0.9 & 1.5 & 1.5 & -0.1 & -0.4 \\
\hline
\end{tabular}

$\mathrm{FCA}=$ foreign currency account, FDI = foreign direct investment, GDP = gross domestic product.

Source: State Bank of Pakistan.

Table 2: Indicators of Openness-Other Countries

\begin{tabular}{lrrrrr}
\hline Indicators & $\mathbf{2 0 0 4}$ & $\mathbf{2 0 0 5}$ & $\mathbf{2 0 0 6}$ & $\mathbf{2 0 0 7}$ & $\mathbf{2 0 0 8}$ \\
\hline Foreign trade (\% of GDP) & & & & & \\
Sri Lanka & 79.5 & 73.6 & 71.2 & 68.6 & 63.2 \\
India & 38 & 42.6 & 47.4 & 45.9 & 50.7 \\
Indonesia & 59.7 & 64 & 56.6 & 54.8 & 58.4 \\
FDI net (\% of GDP) & & & & & \\
Sri Lanka & 1.1 & 1.1 & 1.7 & 1.9 & 1.9 \\
India & 0.8 & 0.9 & 2.2 & 2.1 & 3.6 \\
Indonesia & 0.7 & 2.9 & 1.3 & 1.6 & 1.8 \\
Pakistan & 1.1 & 2.0 & 3.4 & 3.9 & 3.3 \\
\hline
\end{tabular}

FDI $=$ foreign direct investment, GDP = gross domestic product.

Source: World Bank. (2010). World development indicators 2010. Washington, DC: Author. 
Private foreign investment (net of outflows) rose to levels never seen before in Pakistan, peaking at close to USD8 billion in 2007 or 5 percent of GDP (Table 1). Portfolio investment reached an annual level of USD2 billion in the two years preceding the 2008 crisis, while foreign direct investment (FDI) reached USD4.2 billion and USD5.6 billion. FDI remained at USD5 billion in 2008 but declined to USD2.3 billion the following year. However, workers' remittances were the major and more reliable source of foreign flows, which, at close to USD9 billion in 2009, amounted to more than double the 2004 level. In fact, total current transfers (including workers' remittances) remained at roughly 8 percent of GDP during the period.

Table 2 gives the data on net FDI as a proportion of GDP for India, Indonesia, and Sri Lanka, as well as Pakistan. During the period covered, Pakistan received significantly more FDI in relation to its GDP than any of the other Asian countries, although in 2008, India's ratio at 3.6 percent was slightly higher than Pakistan's. However, in interpreting the data, two facts should be considered. First, the data in Table 2 relates to net FDI, not gross inflows. India's somewhat lower ratio may, therefore, be due to its sizable overseas investment. Second, and more importantly, foreign investors' interest in Pakistan has waned with the worsened economic, political, and security situation, while foreign investment in India remains strong and is rising rapidly. During 2004-08, foreign investment in Pakistan went mostly into telecommunications, banking, real estate development, and the purchase of privatized enterprises, but investment opportunities in these areas are now more limited. Thus, in the current state of affairs, it seems unlikely that Pakistan will attract foreign investment at the scale reached during the 2000s.

Another indicator of a country's integration into the global economy is the degree of its dependence on world capital markets as captured by its international investment position relative to GDP (Lane \& Milesi-Ferretti, 2007; Prasad, 2009). Table 3 shows that Pakistan's overall ratio of assets and liabilities during 2004-09 fluctuated from year to year without a clear trend. The ratio peaked at 67 percent in 2007; in other years, it hovered around 60 percent. Normally, a country's international assets and liabilities are expected to be of broadly similar order of magnitude, but in Pakistan's case, assets (consisting mostly of foreign exchange reserves) have averaged only about one third of its international liabilities and its net investment position is strongly negative. 
Table 3: Pakistan's International Investment Position (End-Period)

\begin{tabular}{lrrrrrr}
\hline & $\mathbf{2 0 0 4}$ & $\mathbf{2 0 0 5}$ & $\mathbf{2 0 0 6}$ & $\mathbf{2 0 0 7}$ & $\mathbf{2 0 0 8}$ & $\mathbf{2 0 0 9}$ \\
\hline \% of GDP & & & & & & \\
Assets + liabilities & 63.2 & 59.0 & 58.8 & 67.3 & 53.9 & 62.0 \\
Assets & 17.4 & 16.2 & 15.5 & 15.9 & 11.0 & 14.4 \\
Liabilities & 45.8 & 42.8 & 43.3 & 51.4 & 42.9 & 47.5 \\
Reserves as \% of total assets & 62.8 & 62.5 & 64.3 & 68.2 & 53.5 & 64.8 \\
\% of total liabilities & & & & & & \\
FDI & 17.0 & 21.8 & 24.8 & 34.8 & 23.4 & 21.4 \\
Portfolio & 2.6 & 4.6 & 7.4 & 9.2 & 6.7 & 4.6 \\
Foreign loans & 76.1 & 69.2 & 63.6 & 53.1 & 66.3 & 67.0 \\
\hline
\end{tabular}

$\mathrm{FDI}=$ foreign direct investment, GDP = gross domestic product.

Source: State Bank of Pakistan.

A comparison with India regarding this indicator shows a pattern similar to the other indicators. According to the data reported in Prasad (2009), India's net international investment position just a few years ago was considerably lower than Pakistan's, but the ratio rose rapidly over time, reaching 70 percent of GDP in 2009. Another significant difference between the two countries is that, while gross assets relative to GDP rose steadily in India-thanks to the large accumulation of foreign exchange reserves-they declined for Pakistan. Also, in Pakistan's case, foreign loans account for about two thirds of its liabilities, whereas this ratio for India is about 45 percent.

Figure 1 gives the leading indices for the stock markets in Bombay (SENSEX), Seoul (KOSPI), Kuala Lumpur (KLCI), and Karachi (KSE100), covering the period 2001-09. The indices track the growth in the hypothetical value of the stock, starting with an investment of 100 local currency units on 31 January 2001. It is evident from this figure that, while all four indices displayed broadly similar behavior over time (the rises and falls had some synchronicity), the Karachi Stock Exchange (KSE) was an outlier while the other three markets were more closely clustered. The KSE was also much more unstable, although it yielded a much higher average return on investment. As observed in Haque (2010):

An investment made at the start of the period was worth more than ten times its original value at its peak in early 2008 in Karachi, compared to about four times the initial investment in Bombay, $2 \frac{1}{2}$ times in Seoul and twice the 
invested amount in Kuala Lumpur. Even after the sharp fall in the share prices in 2008, the overall return in the Karachi market remained much higher than in the other markets. The average annual return in Karachi was 34 percent, 26 percent in Bombay, 15 percent in Seoul, and barely 9 percent in Kuala Lumpur, indicative of, among other things, the relative riskiness of investment in the different markets (p. 19).

Figure 1: Selected Stock Indices

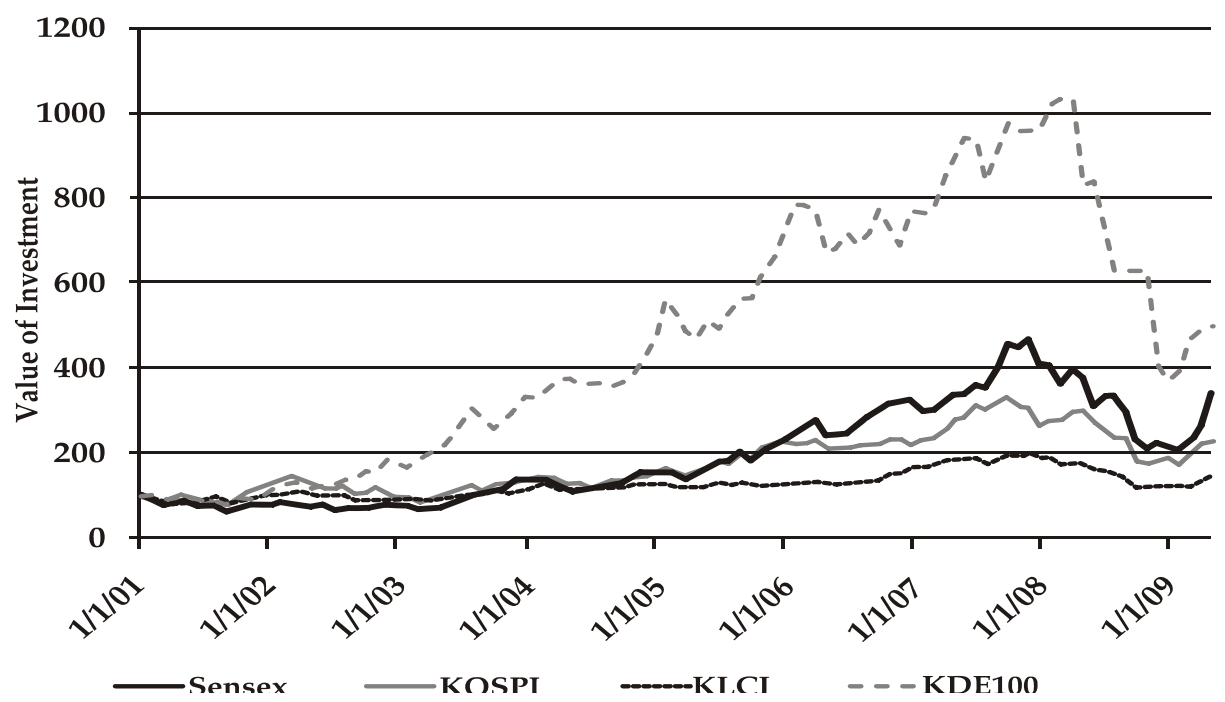

Source: I. Haque. (2010). Pakistan: Causes and management of the 2008 economic crisis (Global Economic Series No. 22). Penang, Malaysia: Third World Network.

Table 4 gives data on price-earning ratios (peaks as well as troughs) in the four countries. As a flip side to the higher returns, the price-earning ratios in the KSE were found to be consistently below the ratios in the other three markets. This is not indicative of generally underpriced stocks but rather a reflection of the Karachi market being riskier and relatively insulated. In comparison to the other Asian markets, the KSE is quite small and dominated by a few large firms in oil and gas, electricity supply, and banking. It earned a reputation for excessive speculation, and charges of price fixing, insider trading, and government involvement were common in the Pakistani media a few years ago, although no official inquiry was made. 
Table 4: Price-Earning Ratios in Selected Markets (2005-08)

\begin{tabular}{lccccc}
\hline & High & Low & Current & Average & H/L ratio \\
\hline Bombay & 24.96 & 8.06 & 18.28 & 18.88 & 3.1 \\
Karachi & 16.61 & 6.31 & 12.11 & 11.54 & 2.63 \\
Kuala Lumpur & 22.58 & 8.63 & 14.28 & 22.47 & 2.62 \\
Seoul & 34.62 & 8.33 & 15.8 & 34.39 & 4.16 \\
\hline
\end{tabular}

Source: I. Haque. (2010). Pakistan: Causes and management of the 2008 economic crisis (Global Economic Series No. 22). Penang, Malaysia: Third World Network.

Overall, the Pakistan economy's exposure to the global economy is not as great as that of some other emerging market economies. Foreign trade relative to its economic size is comparatively small, but it nevertheless remains highly vulnerable to terms-of-trade shocks emanating in the oil and food grain markets. There were sizable private capital inflows during the past decade, but they have since fallen in absolute and relative terms for the reasons discussed. Only a few years ago, Pakistan could be regarded about as integrated into the global economy as India, but over the years, the latter has rapidly moved ahead in terms of virtually all relevant indicators. However, India itself is rather less globalized than most other emerging market economies. According to Prasad (2009), India remains "well below the levels [of integration] attained by most other emerging market economies, including other BRIC economies" (p. 12). This would suggest that Pakistan has considerable catching up to do if it also seeks the path followed by other rapidly globalizing economies. However, the question whether this is a desirable or a feasible goal does not have an easy answer, given the other pressing politico-economic challenges that Pakistan currently faces.

\section{Macroeconomic Consequences}

An open capital account is meant to give a country better access to foreign sources of finance, thereby permitting higher investment and economic growth. Readily available foreign finance should also enable countries to diversify risk and thereby attain greater stability in consumption when output fluctuates. However, the actual realization of these benefits has been found to be, at best, elusive.

There is no clear evidence that financial globalization has raised investment rates and accelerated economic growth in the developing world. Rodrik and Subramanian (2008) find no correlation between an open capital account and higher investment rates; if anything, the 
relationship is found to be negative. In cases where there is a positive correlation between liberalized capital accounts and higher growth rates, the direction of causation is not clearly discernable when the effects of other factors are controlled. At the same time, there is strong evidence that rapid financial globalization brought about greater consumption volatility in the emerging market economies (Rodrik \& Subramanian, 2008). In short, the conclusion of Kose and Prasad (2004) is that the evidence on the benefits from capital account liberalization is not "compelling."

Eichengreen, Gullapalli, and Panizza (2009) are no more reassuring. They find that the positive results of financial globalization are confined basically to high-income countries and are contingent on "well-developed financial systems, good accounting standards, strong creditor rights, and rule of law" (p. 5). ${ }^{6}$ Presumably, countries with that quality of economic management and institutions would not typically be poor.

There is now wide agreement that uncontrolled and unregulated capital movements increase the risk and exposure of emerging market economies to the vagaries of global finance, which is notorious for its "irrational exuberance" and "panics and manias." Reinhart and Rogoff (2008) note: "Periods of high international capital mobility have repeatedly produced international banking crises, not only famously as they did in the 1990s, but historically" (p. 8).

This section explores the extent and nature of the impact of capital account liberalization and rupee convertibility on the Pakistan economy. This is done first by ascertaining the possible impact of foreign capital inflows on domestic investment in recent years, and then investigating whether capital flight was a significant contributor to the 2008 economic crisis.

\section{Impact on Investment}

Whether or not external finance helps a country's economic growth depends in the first place on the constraints to investment. If, for some reason, a country does not have many exploitable profitable opportunities, the availability of finance alone is unlikely to raise the investment rate. Foreign resource inflows are likely then to go into financing consumption (Rodrik \& Subramanian, 2008).

\footnotetext{
${ }^{6}$ Establishing a relationship between financial globalization and outcomes has become somewhat of a growth industry. The literature is vast. Two other useful studies, not mentioned in the main text, are Edison, Klein, Ricci, \& Sløk (2004) and Henry (2007).
} 
During the period 2002-07 as a whole, Pakistan received a total of USD62.2 billion in foreign inflows, which represented roughly 80 percent of exports and about 60 percent of imports. ${ }^{7}$ Workers' remittances were by far the single biggest source of foreign exchange, accounting for 40 percent of the net resource inflows. FDI reached the unprecedented level of about USD12 billion and portfolio investment USD5 billion. Net foreign borrowing during the period was actually negative, i.e., the country's outstanding external debt declined. How this large increase in foreign resource inflows was utilized could provide an indication of whether it promoted the growth of the Pakistani economy.

Table 5 gives data on the trade deficit, gross domestic investment in aggregate, private sector investment, and gross domestic savings (measured as a residual). The trade deficit (measuring net foreign resource inflows) rose from 6 percent of GDP in 2004 to 11 percent of GDP in 2006 and 2007. The ratio was even higher in 2008 but it was essentially a consequence of the sharp drawdown of foreign exchange reserves and the deceleration of GDP growth.

Table 5: Investment, Savings, and Trade Balance

\begin{tabular}{lrrrrrr}
\hline & $\mathbf{2 0 0 4}$ & $\mathbf{2 0 0 5}$ & $\mathbf{2 0 0 6}$ & $\mathbf{2 0 0 7}$ & $\mathbf{2 0 0 8}$ & $\mathbf{2 0 0 9}$ \\
\hline As a percentage of GDP: & & & & & & \\
Import of goods and services & 25.1 & 29.6 & 30.7 & 29.8 & 32.7 & 24.2 \\
Export of goods and services & 16.4 & 17.4 & 16.1 & 15.3 & 15.5 & 13.7 \\
Trade balance & -6.1 & -9.3 & -11.4 & -10.9 & -13.7 & -7.9 \\
Current account balance & -0.8 & -3.3 & -5.3 & -5.8 & -9.6 & -2.2 \\
Gross domestic investment & 15.0 & 17.5 & 20.5 & 20.9 & 20.5 & 17.4 \\
Gross private investment & 10.9 & 13.1 & 15.7 & 15.4 & 15.0 & 12.7 \\
Gross domestic savings (res.) & 8.9 & 8.2 & 9.1 & 10.0 & 6.7 & 9.5 \\
& & & & & & \\
Change in trade balance & & -3.2 & -2.1 & 0.5 & -2.8 & 5.8 \\
Change in investment & & 2.5 & 3.0 & 0.4 & -0.4 & -3.1 \\
Change in private & & 2.2 & 2.6 & -0.3 & -0.4 & -2.3 \\
investment & & & & & & \\
\hline
\end{tabular}

GDP $=$ gross domestic product.

Source: World Bank. (2010). World development indicators 2010. Washington, DC: Author.

On the whole, the rise in net foreign inflows corresponded closely to the rise in the investment rate, which rose from 15 percent to over 20

7 This data is taken from Table 3 in Haque (2010), which also provides other related data and a discussion on the macroeconomic developments of that period. 
percent during 2004-08, while domestic savings rate remained more or less unchanged at under 10 percent. ${ }^{8}$ The close relationship between net resource inflows and investment is more easily seen in the year-to-year changes in the two variables (also given in Table 5). In fact, as the foreign inflows were mostly private, the correspondence with domestic private investment can be seen to be even closer.

In brief, the inflow of foreign capital during the period under consideration appears to have gone primarily into raising the investment rate rather than consumption. Domestic savings in Pakistan remained abysmally low, financing barely half of domestic investment. The high dependency on foreign sources to finance domestic investment has made Pakistan's economic performance highly vulnerable to outside factors. There is little question that this dependency will have to be reduced and domestic savings rate drastically raised if economic growth in Pakistan is to reach levels comparable to the rapidly growing Asian economies. As Rodrik and Subramanian (2008) note, countries that "grow more rapidly are those that rely less and not more on foreign finance; and in turn foreign capital tends to go to countries that experience not high, but low productivity growth" (p. 2).

While the large inflow of external finance into Pakistan cannot be wholly attributed to the country's open capital account, portfolio investment would probably have stayed away in the presence of restrictions on capital movements and rupee convertibility. FDI too was likely encouraged by the rupee convertibility and granting of unrestricted repatriation of profits and gains from the disposal of investments. The rupee convertibility must also have contributed to the quantum jump in workers' remittances and other private transfers, although other factors were also important (see Haque, 2010).

\section{The 2008 Crisis}

Pakistan lost about USD6 billion dollars in foreign exchange reserves in the fiscal year (FY) 2008 and continued to lose for the next several months, reaching a precariously low level in November. This was a sharp turnaround from the situation in the preceding five years, when the country had accumulated sizable foreign exchange reserves. Taking into account the increase in reserves of USD4 billion in FY2007, the net change in the reserve position between the two years amounted close to USD10 billion.

\footnotetext{
8 The year 2008 was an exception when the savings rate fell to under 7 percent on account of the economic crisis.
} 
There were widespread reports of massive capital flight during the crisis (a figure of USD5 billion was often mentioned) but there is no hard evidence to substantiate them. ${ }^{9}$ Some observers privately surmise that the capital flight took the form of Pakistani rupees being taken out of the country in hard cash and then converted into dollars or other currencies in foreign markets, notably Dubai. It is not clear what foreign buyers intended to do with the purchased rupees, but this is a terrain of conspiracy theories. The fact, however, is that the official balance of payments data throws little light on this phenomenon. Undocumented capital movements normally show up under "errors and omissions," but this item was quite small and positive in the official accounts in FY2008 (see Table 6). All the same, it does not appear that the capital outflow was a major reason for the decline in the reserves, and this is for three reasons. ${ }^{10}$

Table 6: Changes in FY2008 Balance of Payments

\begin{tabular}{lcc}
\hline & $\begin{array}{c}\text { Change } \\
\text { FY2008 over } \\
\text { FY2007 (USD } \\
\text { million) }\end{array}$ & $\begin{array}{c}\text { Change as a } \\
\text { Percentage } \\
\text { of FY2007 } \\
\text { GDP }\end{array}$ \\
\hline Current account balance & $-7,158$ & -5 \\
Trade balance & $-5,584$ & -3.9 \\
Exports f.o.b. & 2,844 & 2 \\
Imports f.o.b. & $-8,428$ & -5.9 \\
Services (net) & $-2,464$ & -1.7 \\
Current transfers net & 890 & 0.6 \\
of which: Workers' remittances & 957 & 0.7 \\
Public borrowing and other capital flows (net) & $-1,618$ & -1.1 \\
Private medium and long-term (net) & $-1,408$ & -1 \\
of which: FDI & 52 & 0 \\
Portfolio investment & $-1,800$ & -1.3 \\
Other capital (including errors and omissions) & 544 & 0.4 \\
Change in foreign exchange reserves* & 9,640 & 6.7 \\
\hline
\end{tabular}

* The (-) sign implies an increase in reserves and a (+) sign implies a decrease. FDI = foreign direct investment, FY = fiscal year, GDP = gross domestic product.

Source: Calculations from: I. Haque. (2010). Pakistan: Causes and management of the 2008 economic crisis (Global Economic Series No. 22). Penang, Malaysia: Third World Network.

\footnotetext{
9 The SBP's data reports a net fall of only USD51 million in FCAs during 2008, compared to an increase of about USD450 million in the preceding years (see Table 1).

10 The nature and causes of the 2008 crisis is the subject of Haque (2010); here, the objective is to dispel some common misperceptions.
} 
One way of establishing what caused the decline in reserves is to examine the components of change in the balance of payments between FY2007 and FY2008 (see Table 6). On the capital account side, there was a sharp decline in portfolio investment (a net change of USD1.8 billion) while the level of FDI remained virtually unchanged. Net foreign loan inflows also declined, contributing USD1.6 billion to the deterioration in the balance of payments. On the positive side, workers' remittances rose by about USD1 billion. Taken together, the total decline in resource inflows to Pakistan amounted to about USD2 billion, or one third of the decline in foreign exchange reserves.

Thus, it was the trade deficit-rather than the decline in capital flows-that was by far the bigger cause for the loss of foreign exchange reserves during the crisis. The trade deficit rose to 14 percent of GDP in 2008, representing a 3-percentage point increase over the preceding year, and the surge in imports was the main factor, amounting to an increase of USD8.4 billion or 30 percent. Although the spike in the prices of oil and other imports was a major contributing factor, the import volume alone increased by more than 10 percent-a growth rate some 40 percent higher than the overall growth of the economy.

The deterioration in the trade balance, however, was not a sudden development. Imports had been rising much faster than exports for several years, and it had become apparent quite early that these were not sustainable trends and that the balance of payments would become untenable as soon as the resource inflows slowed down. Pakistan's net international investment position (i.e., foreign assets net of liabilities) had already sharply worsened in 2007, by some USD15 billion or almost 9 percent of GDP

The relative stability of the Pakistani rupee during the crisis is the second factor suggesting that capital movements were not the main culprit. Although the rupee depreciated by one third between March and November 2008, it happened gradually over several months. Despite pervasive and persistent fears about the rupee value, there was no largescale panic selling or a collapse of the currency, as is usual when capital flight results in a sharp fall in foreign exchange reserves. The SBP did take steps to curb speculative activity, ${ }^{11}$ but judging from the experience of other central banks in similar situations, these measures could not have

\footnotetext{
11 These included an increase in the percentage of foreign remittances surrendered to the SBP and new restrictions on advance payment for imports (SBP, 2008a).
} 
withstood a speculator onslaught. In any case, such capital flight as did occur seems to have been offset by flows in the opposite direction.

Finally, the fact that the domestic banking sector managed to avoid undue stress and remained generally solvent would also suggest that the genesis of the crisis did not lie in the financial sector. The IMF's (2009a) assessment was that the banking system had remained adequately capitalized and liquid, even as the deteriorating economic situation and tightened monetary policy had hurt bank profitability and asset quality (p. 10) There was a rise in the ratio of nonperforming loans to banking assets on account of loans to private consumers and the textile sector, while medium and smaller banks also faced distress. All the same, direct exposure of the banking system to currency depreciation or indirect exposure through unhedged operations remained limited.

While capital movements were not found to be a major cause of the loss of foreign exchange reserves, they were probably consequential in other ways. The withdrawal of portfolio investment in 2008 was by no means insignificant and it would have been even larger-and the drop in the stock market steeper-had floor limits on stock trading not been imposed to prevent that from happening. To put it differently, if matters had been left entirely to the market, the financial crisis could have been far more severe. This suggests that, even under an open capital account, government measures can be important in damage control.

A related fact is that the large capital inflows in the years preceding the crisis had made the economy more susceptible to a financial crisis. This happened in two ways. First, foreign financing helped to sustain the rapidly increasing import bill, which was itself a consequence of the expenditure-enhancing growth policies that did little to improve competitiveness of the tradable sectors (Haque, 2010). Second, foreign capital inflows fed the boom in the stock market and real estate, which had made Pakistan increasingly vulnerable to speculators' expectations. At the peak of the boom in 2007, foreign portfolio investment accounted for over 10 percent of the market capitalization of the KSE. This may not be a large figure but it was evidently significant enough to create "irrational exuberance" in an otherwise quite thin market. With regard to the real estate market, the actual magnitude of foreign investments is not known, but there were widespread reports that these too were large and causing sharp increases in real estate prices (Adil, 2006). 
In short, capital flight might not have triggered the 2008 crisis but there can be little doubt that large capital inflows during the 2000s contributed to creating conditions that ultimately led to the crisis. This is not to question the usefulness of foreign capital, but rather to point out that it could have been utilized to lay the foundations of long-term sustainable growth through appropriate public policy and investment rather than to creating an illusion of wealth.

\section{Macroeconomic Policy Challenges}

Pakistan proceeded early and quite far in opening up the capital account and making the rupee convertible, but this was more or less an ad hoc process driven primarily by a need to access foreign exchange, not part of a coherent national economic strategy. However, its actual integration into the global economy in foreign trade and capital markets remained limited as compared to other emerging market economies. Nevertheless, capital account liberalization had important consequences for Pakistan. In particular, financial globalization made macroeconomic management-notably, exchange rate management-more complicated, while unrestricted fund transfers made tax evasion easier. Foreign portfolio investment contributed to the stock market bubble of 2007, and while its benefits for the overall economy are not certain, it entailed real costs that need to be considered. Each of these three areasmacroeconomic management, the problem of tax evasion, and management of portfolio inflows-presents a range of challenges for Pakistan's policymakers.

\section{Macroeconomic Management}

It is axiomatic that macroeconomic policy in an economy with an open capital account is additionally constrained. Apart from the usual domestic political pressures, policymakers in a setting of internationally mobile finance and convertible currencies must also anticipate the response of foreign ${ }^{12}$ players to their actions or inactions. A loss of confidence in economic management or simply a delay in policy announcement can play havoc with the country's currency value and foreign exchange reserves. A sharp fall in the exchange rate can wipe out overnight the balance sheets of banks with high exposure in foreign currencies, resulting in a freeze-up of the entire financial system.

\footnotetext{
12 The term "foreign," when finance flows freely, should be taken to include residents with foreign accounts and investment interests. Their motivations and behavior are indistinguishable from those of the strictly foreign money movers.
} 
That Pakistan avoided getting caught in a similar situation is partly because much of its resource inflows were in the form of workers' remittances and other private transfers, but also because the country, for a variety of reasons, remained more or less insulated from the upheavals in the world's financial markets. Thus, it was not the Great Recession but rather domestic policy failures that brought on Pakistan's 2008 economic crisis (Haque, 2010). In a perverse fashion, the heightened insecurity, political unrest, and serious economic difficulties have also shielded it from hot money flows that have put serious strains on a number of other emerging market economies. Adversity can have a bright side.

The core macroeconomic challenge for policymakers in an open economy is to maintain satisfactory economic growth while keeping the balance of payments manageable. Mobile finance, driven by international arbitrage, is liable to pull the exchange rate in one direction while a desired reduction in the trade deficit may require adjustment in the opposite direction. Thus, for example, the authorities may maintain high interest rates to curb domestic inflation, but this could encourage foreign inflows and bring about a currency appreciation, creating difficulties for exporters. Several emerging market economies-notably, Brazil, India, and Russiaface such a situation. Conversely, the authorities might be impelled to reduce interest rates to promote economic growth and discourage unwanted foreign capital, but this is liable to feed domestic inflation. Very broadly, this situation prevailed in Pakistan around 2003-04.

Managing the exchange rate while pursuing economic growth and stability under an open capital account regime is a daunting task. The problem is that the economic benefits of capital mobility depend on investors seeking real returns, not speculative gains, which is difficult when exchange rates fluctuate. On the other hand, for the exchange rate to be an effective policy tool, it needs to be shielded from speculative capital movements (see Haque, 2001, for this and related issues). Economic theory holds that a country cannot simultaneously have an independent monetary policy and stable exchange rate while maintaining an open capital account. This has been labeled in the literature as the "impossible trinity," i.e., a country must give up one of the three policy pillars (see Zaidi, 2006, for a discussion on this issue in Pakistan's context).

However, policy choices in practice are seldom so stark, and policymakers tend to just muddle through. Pakistan provides a good example of that. It is a country with an ambiguous exchange rate policy, where the rupee is notionally free and convertible but in reality remains 
pegged to the US dollar. Adjustments in the exchange rate are made from time to time but are driven by multiple objectives, i.e., keeping exports competitive, ensuring a satisfactory level of foreign exchange reserves, and restraining speculation. However, this policy has not been particularly successful on any front (Janjua, 2007).

In the aftermath of $9 / 11$, Pakistan received large inflows of foreign money, initially mostly workers' remittances and other transfers but later also private foreign investment. The rapid build up of foreign exchange reserves consequent to these inflows presented the authorities with the dual challenge of keeping inflation under control (dictated also by the IMF) while maintaining a competitive rupee value. But there was also another policy imperative: to stimulate economic growth. Despite the easing of the resource constraint, private domestic investment had remained hesitant and the economy was stuck in sluggish growth. This was at a time when India-Pakistan's principal rival-had embarked on a trajectory of rapid growth and was attracting a great deal of foreign investor interest (Haque, 2010).

Policymakers in Pakistan had little room for maneuver in stimulating economic growth through public expenditures because of commitments to the IMF to reduce the large fiscal deficit. It is at that juncture that the SBP-backed by the executive and finance ministrydramatically loosened monetary policy while continuing to pursue economic liberalization (see SBP, 2003). Interest rates over a span of a few months were drastically reduced for all types of credit, including consumer loans. The choice made was that, instead of sterilizing foreign exchange reserves, an expansionary monetary policy would prevent the rupee from appreciating.

This was a risky policy for many reasons. For one thing, it was based on a misdiagnosis: the Pakistan economy at that point was not demand-constrained that it required easy finance. For another, Pakistani borrowers had a poor record of loan repayment and there was no assurance that cheap credit would stimulate investment rather than consumption. In fact, consumer loans just financed private consumption. The result was that the rapidly rising demand, while lifting economic growth a little, spilled into imports and increased the trade deficit, which laid the basis for the subsequent balance of payments crisis. At the same time, the loose monetary policy combined with rising foreign inflows fed the bubbles in the stock market and real estate. This could only make a bad situation worse. 
In the aftermath of the 2008 crisis, the economic management has been tasked to bring down the fiscal deficit and inflation, in pursuant to its undertakings to the IMF. Apart from fiscal measures, this has entailed a sharp increase in interest rates and a restraint over monetary expansion. Since the large depreciation of 2008, however, the Pakistani rupee has moved only a little: from about PKR80 for a US dollar to the current rate (July 2011) of PKR85. Because of the prevailing high domestic inflation, real interest rates are not unduly high (some are actually negative), but a foreign investor is primarily concerned with the risk of rupee depreciation (leaving aside the country risk). The high nominal interest rates with a virtually unchanged exchange rate have yielded exceptionally high real returns in terms of the leading foreign currencies. The magnitude of carry trade-as this phenomenon is called-in Pakistan is not known, but anecdotal evidence suggests that financial arbitrage is not insignificant. Some surmise that the recent surge in remittances may also have something to do with it. At any rate, it is the Pakistani nation that ultimately bears the cost of the gains-which have little to with the real economy-captured by investors (who could be residents or nonresidents).

Pakistan's competitiveness in trade is also a critical policy issue because long-term economic growth hinges on it. A number of leading Pakistani economists blame the large trade deficits on an overvalued exchange rate and argue for an aggressive exchange rate adjustment to deal with the problem (see, for example, Government of Pakistan, 2008).

This is, however, unlikely to be either practical or particularly useful. There is little evidence that the rupee was seriously overvalued in the pre-crisis period. According to the IMF's International financial statistics (2009b), the "real effective exchange rate" of the rupee had appreciated by about 7 percent by 2008 compared to its value in 2000 . The overvaluation actually reached its highest level in 2004, when it stood at 10 percent, which suggests that, during the years of the rapidly rising trade deficits, the real effective exchange rate had, if anything, declined. The IMF too, in its first report after the 2008 crisis, took a rather benign view of the competitiveness of the Pakistani rupee.

It is also not clear what a regime of active exchange rate management would involve. A consensus on a "competitive" real exchange rate is unlikely and its actual attainment, with freely moving finance, would be well nigh impossible. However, such a policy-while doing little to improve the trade balance-could invite the charge of currency manipulation by the trading partners, with associated penalties. 
More fundamentally, international competitiveness depends not so much on the exchange rate-which can shift the cost advantage in a country's favor only temporarily-but on the growth of labor productivity. Thus, economic management could more usefully be directed toward defining an approach to improving productivity in the tradable sectors.

It is difficult to outline in abstract what a sound macroeconomic policy should be in an open economy. Economic policy is contextual, and there cannot be standard rules regarding the size of what may be considered sustainable budget or trade deficits ${ }^{13}$ or regarding sound monetary policy. A policy can be judged "sound" only ex post, by its results. With freely moving capital, a country's policies must be credible not only to the domestic constituencies but, more crucially, to foreign investors, whose disapproval can bring any economy to its knees. Obviously, a country's economic performance must be "good" in terms of growth and stability, but that may not be enough to attract foreign finance. Investors must also be convinced that the performance will remain good in the future too. A slight slippage in policy can spell major economic and financial disaster in open economies. As Rodrik and Subramanian (2008) put it rather pessimistically: "No matter how much you do, there is still more left to do-and there is always bad luck" (p. 9).

\section{Tax Evasion}

The FCA scheme as applied in the 1990s was costly not just in terms of the tax forgone on interest payments to depositors but also because the accounts were protected against the exchange risk. Domestic banks held their assets in rupees but were given "forward cover" by the SBP on their foreign exchange liabilities, i.e., foreign currency deposits. In other words, it was the central bank that bore the cost of rupee depreciation, which was often considerable. The "no-questions-asked" policy entailed even more serious costs to the country. As a result of this policy, there was a phenomenal growth in foreign currency deposits during the 1990s, reaching USD10 billion in 1998 (amounting to slightly less than six times the level of foreign exchange reserves or about the same magnitude as the value of imports) just before the accounts were frozen (Mirakhor \& Zaidi, 2004). As a way to evade tax, this policy made FCAs particularly popular with Pakistani residents, who came to account for about 80 percent of the holdings. According to one observer, "no-

\footnotetext{
13 Thus, for example, India's budget deficit is not too different from Pakistan's and its trade deficit is also sizable, but that is not considered troublesome, at least for the present.
} 
questions-asked foreign currency deposits were a haven for tax evaders and under-filers ... that could now 'whiten' their ill-gotten income with no taxation and no fear of detection" (Ahmed, 2011, p. 176).

Another peculiarity of the FCAs was that they were not treated as the nation's external debt (underwritten by the SBP), but put under the current account as private transfers, similar to workers' remittances. Thus, interest payments on these accounts were not treated as foreign obligations but were protected against rupee depreciation. This too entailed significant cost for the SBP and the country.

Although by the early 2000s, these problems had been largely resolved, and the spiriting away of tax-free earnings was now more difficult, the culture of tax evasion had become endemic. There are still reports that Pakistani residents are given to converting their rupee earnings from domestic activities into hard currencies (without paying tax) either in an overseas market or through the still existing informal channels of exchange. The funds are then brought back into the country as foreign currency deposits with no trace of their source.

Clearly, something is needed to eliminate or at least minimize these costs. More rigorous application of the existing rules governing rupee exports could help, but given enforcement failures in other areas, this may not amount to much. The existing limit on the amount of rupees a traveler may take is absurdly low (PKR3,000 per traveler) and makes mockery of the regulation itself. For better enforcement of the regulation, the limit will have to be raised to a more realistic level. A more effective deterrent to tax evasion would be the imposition of rigorous reporting requirements on fund transfers, as is done in many developed countries. For example, the US requires that money transfers exceeding USD10,000 be reported whether they are coming into or going out of the country, and US taxpayers are required to declare their foreign accounts at the time of tax filing. Some European countries require a declaration from the recipient that tax has been paid on the incoming funds in an identified jurisdiction.

\section{Portfolio Investment}

Portfolio investment presents challenges for policymakers in developing countries rather similar to the problem of carry trade. Where there are few or no restrictions on capital mobility, foreign portfolio investment is in the nature of hot money: it comes in and goes out of the country with the slightest shift in market sentiment. In thin capital 
markets-as in Pakistan-foreign inflows can be particularly disruptive. Although the country is still struggling with the aftermath of the economic crisis and other disasters, the KSE has once again started to register impressive gains, as a sharp contrast to the state of the rest of the economy.

According to a recent investors' guide (Mobius, 2011), the KSE-100 (the principal index) rose by 28 percent (26 percent in terms of US dollars) in 2010, with profits rising by 14 percent and dividend yields of 5 percent. This was a much better performance than Mumbai, which rose by 17 percent, or Shanghai, which registered a sharp decline. Increased institutional investors' purchases were held to be a major factor in the market's rise. The same guide stated that, at a price-earnings ratio of 8compared to 10 in Shanghai or Manila and 20 in Mumbai-the Karachi exchange was an excellent place to invest. The report even found a silver lining in the 2010 floods because they had caused company valuations to fall while creating the prospect of sizable investments in infrastructure.

The point, however, is not that the above assessment can be taken as reliable for investment decisions, but rather that it illustrates well how market expectations are formed and investors lured into uncharted waters that ultimately cause stock market blowouts. That this may happen again in Pakistan should be considered highly probable.

The benefits of portfolio investment to Pakistan are far from clear or certain. While the KSE's performance might create a buzz among international money centers, in the absence of real economic performance, the capture of gains by some would be, by and large, losses of others. The loss would be for the country if the gainers happen to be mostly foreign speculators and short-term investors. It is probably difficult in Pakistan to re-impose restrictions on capital movements but some means must be devised to curb short-term inflows, which invariably cause more harm than good. Although countries (notably, Brazil) that have imposed such a special tax on short-term capital inflows have not been fully successful, the policy has had some moderating influence.

\section{Concluding Observations}

Over the past two decades, financial globalization has swept the developing world even though its promised benefits remain elusive. Although it was ultimately a national choice by the countries concerned, advisors from international financial institutions and their ilk may have been unduly insistent on the step. The IMF-as an institution and at the 
staff level-has always been favorably disposed to open capital accounts and it had aspired some time ago to have capital account liberalization incorporated into its Articles of agreement. The East Asian crisis, however, intervened to push the issue to the background.

Pakistan today is, for all practical purposes, an open, exposed economy but, as for other countries, the benefits and costs of liberalization measures cannot be weighed with any degree of confidence. It is not possible-and it would be useless-to attempt constructing a counterfactual to which the consequences of Pakistan not adopting the opening-up measures and policies could be traced. In any case, the choice is seldom between staying closed and opening up, but rather in devising a blend of policies optimally suited to the country and its requirements. The reality is that in the present-day economic environment and policy thinking, the country probably had little choice but to swim with the tide. There is little question that, given the difficulties Pakistan faces in enforcing laws and regulations, controls on capital movements and currency convertibility would not have been any more effective.

Capital account liberalization is probably here to stay. Pakistanis have come to enjoy the ease of exchange convertibility, and the reaction in world capital markets to a re-imposition of controls on capital would be quite adverse, at least in the short term. At any rate, tightening de jure controls on capital movements are unlikely to halt disruptive money flows, which continue through a variety of creative channels. Nevertheless, the Great Recession and the experience of other countries have demonstrated that free markets do need to be regulated and unbridled speculation controlled. The regulation of the financial sector and supervision of stock market activities are domains of public policy, but one important test of policy is that financiers-domestic or foreignare not allowed to become the ultimate judges of its soundness. 


\section{References}

Adil, A. (2006, September 21). Pakistan's post-9/11 boom. Lahore, Pakistan: BBC News.

Ahmed, M. (2011). An economic crisis state? In M. Lodhi (Ed.), Pakistan: Beyond the 'crisis state.' Karachi, Pakistan: Oxford University Press.

Dollar, D., \& Kraay, A. (2001). Trade, growth, and poverty. Washington, DC: World Bank.

Edison, H. J., Klein, M. W., Ricci, L. A., \& Sløk, T. (2004). Capital account liberalization and economic performance: Survey and synthesis. International Monetary Fund Staff Papers, 51(2), 220-256.

Eichengreen, B., Gullapalli, R., \& Panizza, U. (2009). Capital account liberalization, financial development and industry growth: A synthetic view (Mimeo). United Nations Conference on Trade and Development and University of California, Berkeley.

Gallagher, K., \& Ocampo, J. A. (2011, April 6). The IMF's welcome rethink on capital controls. The Guardian.

Government of Pakistan. (2008). Economic stabilization with a human face. Islamabad: Author.

Haque, I. (2001). Capital flows, trade in widgets and the exchange rate. Lahore Journal of Economics, 6(1), 1-19.

Haque, I. (2010). Pakistan: Causes and management of the 2008 economic crisis (Global Economic Series No. 22). Penang, Malaysia: Third World Network.

Henry, P. B. (2007). Capital account liberalization: Theory, evidence, and speculation. Journal of Economic Literature, 65(December), 887-935.

International Monetary Fund. (2008). Pakistan. In Annual report on exchange arrangements and exchange restrictions (pp. 1061-1075). Washington, DC: Author.

International Monetary Fund. (2009a). Pakistan: 2009, Article IV consultation, staff report. In IMF country report no. 09/123. Washington, DC: Author.

International Monetary Fund. (2009b). International financial statistics yearbook, 2009. Washington, DC: Author. 
Janjua, A. (2007). Pakistan's external trade: Does exchange rate misalignment matter for Pakistan? [Special Edition] Lahore Journal of Economics, September.

Kose, A., \& Prasad, E. (2004). Liberalizing capital. Finance and Development, September, 50-51.

Lane, P. R., \& Milesi-Ferretti, G. M. (2007). The external wealth of nations mark II: Revised and extended estimates of foreign assets and liabilities, 1970-2004. Journal of International Economics, 73(2), 223250 .

Mirakhor, A., \& Zaidi, I. (2004). Foreign currency deposits and international liquidity shortages in Pakistan (Working Paper No. 04/167). Washington, DC: International Monetary Fund.

Mobius, M. (2011, January 29). Will foreign capital inflows buoy KSE-100 in 2011? South Asia Investor Review. Retrieved from http:/ / southasiainvestor.blogspot.com/2011/01/will-foreigncapital-inflows-buoy-kse.html

Prasad, E. S. (2009). India's approach to capital account liberalization (Discussion Paper No. 3927). Bonn, Germany: Institute for the Study of Labor.

Reinhart, C. M., \& Rogoff, K. S. (2008). This time is different: A panoramic view of eight centuries of financial crises (Working Paper No. 13882). Cambridge, MA: National Bureau of Economic Research.

Rodrik, D., \& Subramanian, A. (2008). Why did financial liberalization disappoint? (Mimeo). Harvard University and Peterson Institute for International Economics.

State Bank of Pakistan. (2003). Monetary and exchange rate policies. Retrieved from http://www.sbp.org.pk/publications/apr/Monetary_Exchange.pdf

World Bank. (2010). World development indicators 2010. Washington, DC: Author.

Zaidi, I. M. (2006). Exchange rate flexibility and the monetary policy framework in Pakistan. State Bank of Pakistan Research Bulletin, 2(1), 115-140. 